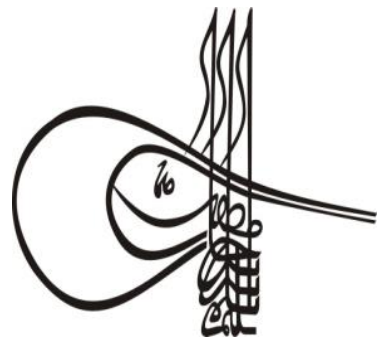

Received/Geliş: 17.02.2019

\section{Turkigh Studies}

Social Sciences

Volume 14 Issue 3, 2019, p. 527-541

DOI: 10.29228/TurkishStudies.22664

ISSN: 2667-5617

Skopje/MACEDONIA-Ankara/TURKEY

Research Article / Araştırma Makalesi

Article Info/Makale Bilgisi

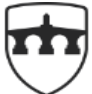

INTERNATIONAL BALKAN UNIVERSITY

EXCELLENCE FOR THE FUTURE IBU.EDU.MK

\Accepted/Kabul: 10.06 .2019

Gor Report Dates/Rapor Tarihleri: Referee 1 (14.03.2019)- Referee 2 (17.04.2019)

This article was checked by intihal.net.

\title{
KANT'IN DEONTOLOJİK ETİĞİNDEN MESLEK ETİĞİ OLUŞTURMA
}

Ayşe EROĞLU*

Dünyada hiçbir șey başkalarının hakkından kutsal değildir (Kant, 2007: 7).

\begin{abstract}
öz
Etik tarihi içerisinde bir etik teorisyen olarak İmmanuel Kant dikkat çekmiştir. Bu çalışma Kant'ın ödev etiğini temel alarak bir ilahiyatçının iş hayatında meslek etiğinin gerekli olduğunu ifade etmeyi amaçlar. Bu çalışmanın yapılmasının ana nedeni, ilahiyat öğrencilerine meslek etiği dersleri verilirken karşılaşılan zorluklardır. Çünkü öğrencilerin bir kısmı bu dersi almanın gereksiz olduğunu düşünmektedir. Bu çalışmanın yapılmasının başka bir nedeni de işletme, tıp mühendislik, hukuk, çevre ve basın gibi alanlarda meslek etiği çalışmalarının daha fazla olmasıdır. Fakat bunun yanında ilahiyat alanında ise bu gibi çalışmaların çok fazla olmadığı görülür. Bu çalışma ile alana katkı sağlamak amaçlanmıştır. Günümüzde sadece ilahiyatçlların değil her meslek mensubunun meslek etiği ilkelerine uyması gerekli olduğu düşünülünce durumun önemi ortaya çıkmaktadır. Fakat her sseyden önemlisi toplumda önemli bir yere sahip olan ilahiyatçının etik ilkelere uyması daha da büyük önem arz etmektedir. $\mathrm{Bu}$ nedenle Kant'n ifadesiyle birey mesleğini icra ederken yasayı kendinden alarak bir ödev bilinciyle etik ilkeleri gerçekleștirebilirse toplum içinde pek çok problemin de önüne geçilmiş olacaktır. Çalışmanın ana hipotezi Kant etiğinden bir meslek etiği oluşturulabilir iddiasıdır. Çalışma böylesi bir etik oluşturma çabası içerisinde geliştirilecektir. Yöntem olarak bu çalışmada Kant'n etik kavramları ve etik anlayışını temel alarak transendental, diskürsif ve analojik bir metotla ilahiyatçı bir meslek etiği oluşturulmaya çalışılmıştır. Çalışma sonuçlarına göre,
\end{abstract}


Kant'in etiği ile meslek etiği oluşturulabileceği ortaya çıkmış ve bu çerçevede birtakım mesleki etik ilkeler oluşturulmuştur.

Anahtar Kelimeler: Etik, Ödev, Yasa, İlahiyatçı, Meslek Etiği

\title{
CREATING PROFESSIONAL ETHICS FROM KANT'S DEONTOLOGICAL ETHICS
}

\author{
Nothing in the World is \\ more sacred than other's rights (Kant, 2007: 7).
}

\begin{abstract}
As an ethical theorist in the history of ethics, Immanuel Kant has attracted attention. This study aims to express that the ethics of Kant is based on the ethics of professional ethics is necessary in the professional life of a theologian. The main reason for this study is the difficulties I encountered in giving the ethics courses to the students of theology. Some of the students think that it is unnecessary to take this course. Another reason for this study is that there are more professional ethics studies in the fields of business, medical engineering, law, environment and the press. However, in the field of theology, it is seen that such studies are not much. With the help of this study it is aimed to contribute to the field. The importance of the situation arises when we consider that not only the theologians, but all the professions should comply with the principles of professional ethics. But above all, it is even more important for the theologian who has an important place in society to adhere to the ethical principles. For this reason, in the words of Kant, the individual will be able to realize the profession by taking the law from himself and if he can realize the ethical principles with a duty consciousness, many problems in the society will be prevented. The main hypothesis of the study is the claim that a professional ethic can be created from Kant ethics. The study will be developed in such an ethical effort. In this study, the ethical concepts and ethical understanding of Kant is based on a transcendental, discursive and analytic method to create a professional ethics of theology. According to the results of the study, it has been revealed that Kant's ethics and professional ethics can be formed and within this framework several professional ethical principles have been established.
\end{abstract}

\section{STRUCTURED ABSTRACT}

Kant has attracted attention as an ethical theorist in the history of ethics. This study aims to express that the ethics of Immanuel Kant is based on the ethics of professional ethics in the professional life of a theologian. The main reason for this study is the difficulties that I encounter while teaching the ethics courses to the theology students. One of these difficulties is that some of the students think that it is unnecessary to take this course. Because students think that theology is purely ethical. As a result of the observations made, it was decided to conduct this study considering the existence of ethical violations in the 
environment where all ethics existed. It is possible to see that there are studies in almost all areas related to professional ethics. It has been observed that these studies were carried out in certain areas. For example, it has been observed that there are more studies in areas such as medical ethics, bioethics, environmental ethics, business ethics, psychological ethics, press and legal politics. Considering all this, it can be said that these studies are less in the field of theology. This study was carried out to answer the needs in this field. The study is not very comprehensive. However, it is planned to contribute to the field. For this reason, an effort has been made to create a deontological professional ethics. Nowadays the importance of the situation arises when it is considered that not only the theologians, but all the professions should comply with the principles of professional ethics. But above all, it is even more important for the theologian who has an important place in society to adhere to the ethical principles.

The main hypothesis of the study is the claim that a professional ethics can be created from the ethics of Kant. Study tries to find answers of the questions such as; What is the basis of Kant's ethics? What are the basic criteria of Kant's ethics? Is Kant's ethics based on mind, or is it based on experience? According to Kant, can ethical principles be formed according to the nature of human beings, such as natural laws? Are our senses in the forefront of ethical laws? Is it possible to base ethical principles on theology? Can a professional ethic be created from the Kant ethics for a theologian? Could the source of the professional ethics be the theology? Is it possible to simulate the basic criteria of professional ethics to the basic criteria of Kant? Is a theologian an autonomous being? As an autonomous being, the theologian can create his / her own professional ethical principles?

In this study, it is tried to create a theological ethic by using transcendental, discursive and analogical method based on Kant's ethical concepts and ethics. Kant uses the transcendental method when basing ethics. Kant set out from the moral experiences of everyday life in which everyone lives and had always searched the cause of this moral law that he had always accepted. Kant re-established this cause as the principle of freedom. Freedom as an autonomous self-determination of autonomy as self-determination, has defined its own law. The reason for the moral necessity is the free and independent will arising out of the liberty and making the law in the name of freedom. In order for this method to be fully functional, Kant is complemented by the principle of freedom and the discursive and analogical method that connects the world of facts to one another. The discursive method is an effort to legitimization and justify the norms that are valid in a society. The analogical method is used to associate the norms and values adopted by the general to a specific situation. By taking into consideration these methods, the basis of a professional ethics is the first to stand on the free will of the profession and to form the law; secondly, to legitimately justify the norms created for the profession; the third is to resemble Kant's ethical laws when creating norms. is to try to establish the ethics of the profession with these three methods.

According to the results of the study, Kant's ethics and professional ethics can be created. It is seen that Kant ethics is based on transcendental, discursive and analogy. While Kant aims to find the 
constituent principle that constitutes the ethics with transcendental method, he especially focuses on free will. He tries to legitimize the norms that are valid by the discouraging method and tries to create other norms for the society. By analogical method, it has related the norms and values adopted by the general public to a certain situation. With this study, a theologian was accepted as an autonomous entity and the norms accepted by the society were tried to be justified. In this respect, Kant's deontological ethic was taken as an example.

According to Kant, creating a professional ethic is based on philosophy. Kant thought that based on philosophy, ethics should be formed based on metaphysics. Because Kant is based on metaphysics, there are those who evaluate his ethics as theological ethical. Perhaps these criticisms stem from Kant's uncompromising expressions with each other. Because Kant, in one place religion says that it does not lead us to ethics; elsewhere, the idea of God leads us to ethics. Leaving these criticisms aside, if Kant has created a theological basis, as it is said, and this ethics forms the basis of deontological ethics, a theoretician ethics can be created based on the Kant ethics. Therefore, it is possible to use it as a religious source in the formation of professional ethical principles. Because even though Kant states that ethics cannot be created from the assets that we attributed to the holiness, he still mentions that the ethic law, expressed in the love of God, strengthens ethics. Thus, for a theologian, ethical laws can be created based on Qur'an and Sunnah. According to Kant, ethics should be based on human beings. Because in the universe, the one who knows the responsibility of his sole actions and who thinks is the man. If ethics is based on man, professional ethics will be based on man. According to Kant, man uses both his mind and experience in creating ethical principles. Because man is a being who thinks, knows and acts. Kant emphasized the nature of human nature and the need to consider the law of nature. He resembled the harmony and consistency in the laws of nature to the nature of human being. According to Kant, ethical laws are carried out together with respect and love, even when action is taken. Kant ethics is based on human, supreme good, good intentions and will as autonomous entity. The ethics of the theologian has been tried to be based on these four principles. As a result, the following ten principles have been determined: 1 . Act according to the law you accept as autonomous! 2. Observe your right in your actions and rule with justice! 3. Do your action in good faith! 4. Do it because not someone says good at you, but it is good to act like that! 5 . Do your work with love and be happy! 6 . Admit yourself as you are, don't kill yourself! 7. Don't let love of yourself ignore the right of others! 8. Act according to the values you know 9. Have a say in the field of being an expert, do not allow non-experts to speak in your field! 10.To be a good theologian, you have the common purpose to bring all theologians together!

The ten principles mentioned above are defined as professional ethical principles for a theologian. By this determination, a deontological professional ethics was formed. There will be those who claim that we are not using the exact method because of our normative method. It can be argued that the rules are set as an authority rather than justifying and legitimizing the norms. Our effort, however, is an effort to transform the individual law of a theologian into a general law. Another subject to be criticized is to make ethical basics from theology. Here Kant is shown as 
a source. The study is an example of studies made in this regard. It also contributes to other studies.

Keywords: Ethics, Professional Ethics, Theologist, Transcendental Method, Freedom

\section{Giriş}

Kitle iletişiminin gelişimiyle birlikte insani ilişkilerde etik değer kayıplarının var olduğunu görmek mümkündür. Her şeyden önemlisi ve endişe verici husus ise evrendeki biricik akıllı varlık olan insanın değerlerinden uzaklaşmasıdır. Bu durum etik değerlerin yozlaşmasına neden olmaktadır. Bunlar arasında en endişe verici olanı insan(lık)ın olmadığı bir toplumun varlığıdır. Bu da genelde toplumu, özde ise insanı ilgilendiren bir durum olarak ayan beyan ortadadır. İnsanın etik ile ilişkisi onun özünden gelir. $\mathrm{Bu}$ nedenle etiği problem edinmek bütün filozofların ana meselelerinden biri olmuştur. Etik felsefesi denildiğinde İmmanuel Kant, etik tarihinin köşe taşlarından biri olarak kabul edilmektedir (Billington, 2011) Kant, etiği temellendirirken transendental ${ }^{1}$ yöntemi kullanır. Kant, herkesin içinde yaşadığı gündelik hayatın ahlâki deneyimlerinden yola çıkar. Herkesin bir şekilde her zaman kabul ettiği bu ahlâk yasası olgusunun nedenini arar. Yani ahlâkiliği temellendirecek kurucu olan nedeni bulmayı amaçlar. Bu nedeni özgürlük ilkesi olarak yeniden kurar. Özgürlüğü otonomi olarak iradenin kendini içten özerk belirlemesi, kendi yasasını kendi koyması olarak tarif eder. Ahlâki gerekliliğin nedeni, bizzat özgürlükten kaynaklanan ve özgürlük adına yasa koyan serbest, bağımsız iradedir (Pieper, 2012). Kant'ın, etik teorisi aynı zamanda deontolojik etik denilir. Onun etik teoriler üzerinde deontolojisinin etkisi o kadar güçlüdür ki bu konuda çalışma yapanlar deontolojiyi Kantyanizm olarak adlandırırlar (Bowie, 2009).

Kant'1n etik ile ilgili eserinin Türkçesi "Ahlâk Metafiziğinin Temellendirilmesi” (Kant, 2013) olarak ifade edilirken orijinal dilinde ise "Grundlegung zur Metaphysik der Sitten" adını alır. Kitabın başlığında geçen Almanca "sitten" kelimesi Türkçe karşllığı olan "etik" ya da "ahlâk" kelimesinin karşılığını ifade etmektedir. Bu durum Kant'ın ahlâk ve etik terimini birbiri yerine kullandığı göstermektedir. Böylece de meslek etiği ya da meslek ahlâkı terimini kullanmanın bir sakıncası olmadığı düşünülebilir. Fakat bu çalışmada mesleki etik kavramını kullanmakla birlikte Kant'ın kullanımı anlamında da ahlâk kavramını kullanmak uygun bulundu. Dolayısıyla hem ahlâk hem de etik kavramlarının her ikisini de çalışma da kullanılmış olundu. Bunun nedeni "Etik" kavramı, Grekçe "ethos", dan "moral" kavramı ise Latince "mos" sözcügünden gelmektedir. Hem "ethos" hem de "mos" töre, gelenek, görenek, alışkanlık, karakter, huy, mizaç anlamlarına gelmektedir (Doğan Özlem, 2004). Moral kavramının Türkçe'de karşılığı Arapça "hulk" kelimesinin çoğulu olan "ahlâk", seciye, teoloji, tabiat, insanın iç dünyasını ve dış dünyasını ifade eder (Erdem, 2012). Günümüzce çeşitli dillerde aynı kökenle kullanmaktadır. Örneğin, Almanca "ethik", Fransızca "ethique" İngilizce "ethics", Latince "ethike", Yunanca "ethica" gibi. Kavramın kökeni "ethos", her şeyden önce "iyi insan olma" anlamında bireysel karakter anlamını içermektedir. Bununla birlikte kavram yabancı literatürde "ethos" olarak bütün bir toplumun niteliğini ortaya koymaktadır. Etik, bir bireyin gerçekleştirmesi gereken kurallardır (Çakıroğlu, 2012). Meslek Etiği (Professional Ethic), mesleki faaliyetin sürdürülmesi aşamasında mesleki ilkelere göre hareket etme disiplini olarak kabul edilir (Çakıroğlu, 2012, s. 60).

\footnotetext{
1"Transendental, Latince üstüne çıkmak, aşmak anlamlarına gelir. Transdental yöntem, indirgemeci bir yöntemdir, ahlakilik kavramının oluşumunu mutlaka kayıtsız şartsız kökenine kadar geri götürüpyeniden kurarak ahlaki eylemin imkanlarını oluşturan kurucu koşulları araştırır.” Pieper, s.184
} 


\section{Bir Meslek Etiği Kurmak}

\subsection{Bir Meslek Etiği Temellendirmesi}

Kant etiğinden bir meslek etiğgi oluşturulabilir mi sorusunun cevabını bulabilmenin birinci yolu Kant etiğini anlayabilmek ve değerlendirmekten geçmektedir. Kant etiği transentendal yöntem ile temellendirir. Kant'ın kullandığı bu yöntemin tam anlamıyla işlevsel hale gelebilmesi için, özgürlük ilkesiyle, olgular dünyasını bir yere kadar birbirleriyle ilintileyen diskürsif ve analojik yöntemle tamamlanmas1 gerekmektedir (Pieper, 2012). Diskürsif yöntem, bir problemi kavramsal argümanlarla enikonu işlemek; bir konuşma biçiminde birlikte irdelemek tartışmak, bir toplumda fiilen geçerli olan normları meşrulaştırma ve haklı kılma çabasıdır. (Pieper, 2012, s. 169). Analojik yöntem, genel tarafından benimsenmiş normları ve değerleri, belli tek durumla ilişkilendirmek için kullanılır. Norm ile mevcut durum durumun birbiriyle ilintilendirilmesi, karşılaştırabilirlik ve oranlanabilirlik esasına göre gerçekleştirilir (Pieper, 2012, s. 184). Bu yöntemleri dikkate alarak bir meslek etiği temellendirme ilk olarak meslek mensubunun özgür iradesi ile yasayı oluşturabileceği üzerinde durmak; ikinci olarak meslek mensubu için oluşturulan normları meşru kılma; üçüncü olarak ise normları oluştururken Kant'ın etik yasalarına benzetmektir. Yani bu üç yöntem ile meslek etiğini temellendirmeye çalışmaktır.

Kant, ilk yasalara ilişkin bilime fizik, diğerlerine ilişkin olana da etik adını verir. Dolayısıyla ilk bilimi doğa öğretisi, ikincisini etik öğretisi olarak nitelendirmek mümkündür. Kant'a göre, öğretileri yanlızca a priori ilkelerden çıkarıp sunmaya saf felsefe denir. Felsefe anlama yetisiyle yetindiğinde buna metafizik denir. Metafiziği hem doğa metafiziği hem de doğa etik metafiziğinin idesini ortaya çıkarır. Nasıl ki fiziğin deneysel ve akılsal kısmı varsa; etiğin deneysel kısmına pratik antropoloji ve akılsal kısmına ahlâk denir (Kant, 2013, s. 2-3). Kant'a göre antropoloji, öznel pratik kurallarla uğraşır, insanın gerçek davranışlarını gözlemler, yalnız ahlâk felsefesi doğru eylemin gerçekleşmesini sağlayan kurallarla ilgilenir (Immanuel Kant, 2007). Kant, insan doğasını felsefi antroplojiyle birleştirir (Westphal, 2009). "İki şey üzerinde sık sı eğilip ısrarla düşünülürse, insanın ruhsal yapısını hep yeni, hep artan bir hayranlı ve korkunç saygıyla doldurur: Üzerimdeki yıldızlı gök ve içimdeki ahlâk yasasl" (Kant, Pratik Aklın Eleştirisi, 1999) der. Bu ifadelerde Kant, doğa ile etiği ilişkilendirmekte ve etiğin içeriğinde hem deneyimin hem de aklın bulunduğunu dile getirmektedir. Ayrıca Kant'ın etik bir değerlendirme yaparken insanı bütün olarak kabul etmesi dikkat çekicidir. O halde Kant, merkezine insanı alarak bir etik temellendirmesi yapmaktadır. Bu durumda bir meslek etiğini temellendirirken hem insanın doğasını hem de doğa kanununu gözönünde bulundurmak gerekir. Bu durumda bir ilahiyatçı için temellendirilecek meslek etiği hem doğa hem de onun içindeki ahlâk yasası dikkate alınarak oluşturulur.

Kant, sırf deneysel ve antropolijiye ait olan her şeyden tamamen arındırılmış saf bir ahlâk felsefesini geliştirmenin son derece zorunlu olduğunu düşünür. Böyle bir etik felsefesinin olanakl1 olmasını sağlayan şey ödev ve etik yasasının idesiyle açığa çıkar. Kant'a göre bilim deneyimsel olarak mümkünken etik ise zorunludur. (Silber, 2012). Ayrıca Kant'a göre bir yasa etik yasası olarak geçerli olacaksa, mutlak zorunluluk taşımalıdır. Söz gelimi, "Yalan söylemeyeceksin." buyruğu bütün akıl sahipleri için geçerli olmalıdır. Etik yasalarının yükümlülük nedenleri insanın doğal yapısında ya da içinde bulunduğu dünyanın koşullarında değil, apriori olarak doğrudan doğruya saf aklın kavramlarında aranır. Etik, kaynağını deneysel temellere dayandırıyorsa pratik kural adını alabilir buna hiçbir zaman etik yasası denemez (Kant, 2013, s. 4) (Immanuel Kant, 2007). Akıl geliştikçe ahlâk yasasının farkına varır. Bu yasanın en temel değeri (veya mutlak, karşılaştırma götürmez değeri), her akıllı varlıktaki aklî doğanın asaleti ve buna bağlı olarak, her akıllı varlığın mutlak eşitliğidir (Wood, 2009). Ayrıca ahlâk, bir rehberden ve doğru yargıda bulunmak için en üstün normdan yoksun olduğu sürece, her türlü bozulmaya açıktır. Nitekim ahlâkça iyi olması için etik yasasına uygun olması yetmez, aynı zamanda etik yasası uğruna yapılmalıdır (Kant, 2013, s. 25). Kant'ın ahlâki görev ve yasaların belirlenmesi ve gerekçelendirilmesi yönteminin kilit noktası yasaklanmış bir eylemi gerçekleştirmek için yeterli gerekçeli gerekçelerin sağlanamayacağını göstermektir. Bir ilkeyi ifade eden bir maxim benimseme 
olasılı̆̆ 1 eylem ve bunun gerekçeleri, bu nedenle, esasen, "'Inan', 'onayla' ya da 'kabul et'.! Evrensellik Kant'ın etik yasalarında yer alan, aracının kendi eylemini içerir ve herkese karşı ve zaman içinde aynı şekilde hareket eden insanların varlı̆̆ını öngörür (Westphal, 2019). Yani Kantçı etik teori özgür iradeye ihtiyaç duymaktadır (Bakış, 2015). Dolayısıyla Kantçı ahlâksal iyilik, insana araçsız, içsel, mutlak bir ahlâk değeri kazandırır. Örneğin sözünü tutan biri, amaç ne olursa olsun, her zaman araçsız içsel bir özgür iradesi ile davranmış olur (Immanuel Kant, 2007). Kant felsefesiyle düşünüldüğünde bir olgunun etik yasası olabilmesi için akla dayanması gerekir. O halde bir meslek etiği yasasının da akla dayandırılarak oluşturulması gerekir. Bir ilahiyatçının meslek etiği için kurallar oluşturulacaksa apriori temele dayandırılır. Çünkü deneyimden gelen kurallar pratik olsalar bile geneli bu kurallara uyum sağlamadığı için ahlâkiliği tam anlamıla sağlamayabilir. Fakat apriori olduğunda durum farklılaşabilir. Ayrıca Kant'a göre etik yasası zorunluluk içerirse bu yasaya uyum tam anlamıyla gerçekleşebilir. Silber'e göre ise Kant'ın etik teorisi deneyimlenebilse bile birtakım eksiklikleri olabilir. Sözgelimi, biri günlük ödevlerinin neler olduğunu bilir. Ancak pratik de ödevlerini gerçekleştirmekte zayıflık gösterir (Silber, 2012). Yani etik yasadaki zorunluluk bazen insanı istemeye istemeye eylemi gerçekleştirmeye yöneltebilir.

"Görev" kavramı sözlükte bir nesne veya bir kimsenin yaptığı iş veya bir kimseye veya bir kurula verilen özel amaçlı iş ve misyon anlamına gelmektedir. "Ödev" kavramı ise sözlükte yapılması, yerine getirilmesi, insanlık duygusu, töre ve yasa bakımından gerekli olan iş veya davranış vazife ve vecibedir (Türkçe Sözlük, 2011). Kant, etiğin faili olarak insanı otonom bir varlık olarak kabul eder ve etik yasanın kaynağı ise bizzat insanın kendisidir. Etik değerlerin kaynağı ise insan aklıdır. Akıl da etik olarak kendisini vicdanla ${ }^{2}$ gerçekleştirir (Erdem, 2012). Kant ödevi ${ }^{3}$ yasaya saygıdan dolayı yapılan eylemin zorunluluğu olarak değerlendirir. Söz gelimi, yapmayı tasarladığım eylemin nesnesine kuşkusuz eğilimim olabilir. Ama hiçbir zaman saygım olmaz çünkü o istemenin bir etkinliği değil etkisidir (Kant, 2013, s. 15). Yani bütün eğilimlerime zarar verse bile böyle bir yasaya uymak maksiminden ${ }^{4}$ başka istemeyi belirleyebilecek bir şey kalmaz (Kant, 2013, s. 16). Yasa zorunlu olacak ama yasayı gerçekleştirme çabası yasaya saygıdan $\mathrm{m}$ ileri gelecek? Yasayı gerçekleştirmek için yasaya saygı duymak gerekliyse bu durumda yasaya saygı duymayan yasayı gerçekleştirmemiş mi olacaktır? Zorunlu bir yasa kişiyi istemeye istemeye eylemi gerçekleştirmeye zorlamış olmaz mı? Kant, yukarıda ifade ettiğimiz sorunları düşünmüş olmalı ki başka bir eserinde de gönlün, ahlâksal zihniyetin ilkesi olduğunu dile getirir. Tanrı ahlâksal iyiliği ister. Ödüle değer olan da budur. Her şey Tanrı'ya duyulan sevgiden dolayı yapılmalıdır. Çünkü Tanrı'yı sevmek onun emirlerini seve seve yerine getirmek demektir (Immanuel Kant, 2007, s. 51). Kant, içindeki etik yasasını idrak eden bir insana Tanrı'nın varlığını ispata gerek olmadığını ve Tanrı olmadan mutluluğa ve kurtuluşa ulaşılamayacağını söyler (Tüzer, 2015). Kant vari bir etiğin, hem saygıyı hem de sevgiyi birarada bulundurması gerekir. Kant'a göre insan bu saygıyı ve sevgiyi Tanrı sayesinde gerçekleştirir. Yani özne ahlâki eylemi gönülden severek yapabilmelidir.

Kant'a göre etiği temellellendirmenin ilk adımı, ahlâklılığın en yüksek ilkesinin aranıp bulunması ve saptanmasıdır (Kant, 2013, s. 7). Kant'ın Ahlâk Metafiziğinin Temellendirilmesi'ndeki amacı, "ahlâkın temel ilkesini araştırmak ve tesis etmektir". (Wood, 2009) Ahlâk Metafiziğinin Temellendirilmesi'nin ilk bölümünde, akıllı ahlâkî fail olmak itibarıla her insanda olduğuna inandığı

\footnotetext{
2"Vicdan, insanın kendini ahlâk yasalarına uymasını sağlayan içgüdüdür. Her vicdan doğaldır, bunun temelinde doğaüstü ya da vahyedilmiş bir yasa olabilir. Vicdan tanrısal mahkemeyi içimizde tasarlar. Demek ki vicdan tanrısal mahkemenin içimizdeki temsicisidir" bkz.Kant, Ethica Etik Üzerine Dersler, s.153,158.

${ }^{3}$ Ödev, (İng.duty, Fr. Devoir, Al. Müssen sollen) Kişinin insanlığına, yüceliğine, sorumluluğuna bakılarak, gerçekleştirilmesi istenen ve beklenen eylem veya eylemler kümesi. Ahmet Cevizci, Felsefe Sözlüğü, Paradigma Yayınları, İstanbul 2000, s.715; Vazife, Bir adamın ifasına mecbur olduğu iş. Şemseddin Sami, Kamusı Türki, Haz: Paşa Yavuzarslan, Türk Dil Kurumu Yayınları, Ankara2015, s.1301

${ }^{4}$ Maksim, istemenin öznel ilkesidir, nesnel ilke (yani arzulama yetisine tam egemen olsaydı, bütün akıl sahibi varlıklar için öznel olarak da pratik ilke işini görecek ilke) ise pratik yasadır. Kant a.g.e.s.16
} 
ahlâkî yol yordam bilgisinden ya da "ortak aklî ahlâkî bilgi" dediği şeyden, söz konusu ilkenin bir formülasyonunu türetmeye çalışır. Kant'ın burada başlıca amac1, türettiği ilkeyi, ahlâk duygusu kuramcılarının tercih edebileceği ilkelerden, ahlâkı davranışlarımızın insan mutluluğu bakımından sonuçları üzerinde temellendirenlerden ayırt etmektir (Wood, 2009). Kant, insanları gerek kendi şahsında gerekse başkasının şahsında her zaman, sadece bir araç olarak değil de aynı zamanda bir amaç olarak kullanacak şekilde eylemde bulunmas1 gerektiğini önceler (Pieper, 2012, s. 81). Kant'in en yüksek yasası: "Hep aynı zamanda yasa olarak genel olmasını isteyebileceğin maksime göre eylemde bulun" bu bir istemenin kendisiyle çatışmaya düşmeyeceği tek koşuldur böyle bir buyruk da kesindir (Kant, 2013, s. 54-55). En yüksek ilke akılda bulunur ve eylemi yerine getirten ahlâksal itici güç de yürekte bulunur (Immanuel Kant, 2007). Bir ilahiyatçı için en yüksek ilke ne olmalıdır? Böylesi bir ilkeyi saptamak kolay mıdır? Bütün ilahiyatçıları içine alacak en yüksek bir ilke var mıdır? Bu soruların cevabının bulunması gerekmektedir. Kendi maksiminin genel bir yasa olmasını her ilahiyatçının gerçekleştirmesi mümkün müdür? Bu sorular cevaplandırılıp böylesi bir ilke bulunursa bu ilke ile bir meslek etiği kurulabilir. Belki sadece bu ilke pek çok ilkeye kaynaklık edebilir. Kant en yüksek ilkeyi şu şekilde de ifade eder: "Dünyadaki mümkün en yüce iyilik senin nihai amacın olsun!” (Kant, Saf Aklın Sınırları Dahilinde Din, 2017). O halde bir ilahiyatçı için en yüksek ilke mesleği icra ederken kendisinden beklenilenin en iyisini yapmaktır.

Kant, isteme için zorlayıcı olduğu ölçüde nesnel bir ilkenin tasarımına emir bu emrin formülüne de buyruk der (Kant, 2013, s. 29). Her bakımdan iyi olan bir isteme, aynı şekilde nesnel yasalara (iyinin yasalarına) bağlı olur ama bundan dolayı yasaya uygun eylemlere zorlamış olduğu tasarımlanamaz; çünkü o, kendiliğinden öznel yapısına göre ancak iyinin tasarımı tarafından belirlenebilir. Bu nedenle tanrısal ve kutsal bir isteme için buyruklar geçersizdir. Bütün buyruklar, koşullu olarak ya da kesin olarak buyurulur. Illk buyruklar insanın ulaşmak istediği veya isteyebileceği başka bir şeye araç olarak olanaklı bir eylemin zorunluluğunu ortaya koyar. Kesin buyruk ise, bir eylemi kendisi için başka herhangi bir amaçla ilgi kurmadan nesnel zorunlu olarak sunan buyruk olur (Kant, 2013, s. 30). Ona göre, bütün buyruklar bir gerekliliği ifade eder. Pratik iyi ise, aklın tasarımlarıyla, dolayısıyla öznel nedenlerle değil, nesnel yani her akıl sahibi varlık için böyle bir varlık olarak geçerli olan nedenlerle istemeyi belirleyen şeydir. Buyruğa tekrar geri dönersek eğer eylem sırf başka bir şey için araç olarak iyi olacaksa buyruk koşullu olur (Kant, 2013, s. 31). Öyleyse kesin buyruk tek bir tanedir. Hem de şudur: ancak aynı zamanda genel bir yasa olmasını isteyebileceğin maksime göre eylemde bulun (Kant, 2013, s. 38) (Frenkena, 2007). Bazı teorisyenler Kant kesin buyruk fikrini öne sürmüştür, ancak uygulayamamıştır. Sonuçta, kategorik emir kipi, ahlâki açıdan gerekli olan sonları bize taahhüt eder. Ancak görev veya yükümlülük çatışmaları ahlâki ikilemleri beraberinde getirmesi de kaçınılmazdır (Timmermann, 2013). Bu eleştrileri bir kenara bırakırsak bir ilahiyatçı için oluşturulacak meslek etiği ilkeleri Kur'anı Kerim ve Sünnet kaynaklı mı olmalı mıdır? Kaynăgını dinden alan bir mesleki etiğinin varlığı kabul edilebilir mi? Çünkü Kant'a göre, din ahlâkın kaynağı değildir. Tersine ahlâk yasalarının Tanrı bilgisine uygulanmasından ileri gelir. Her din, ahlâkı şart koşar, bu nedenle ahlâk dinden üretilemez. Fakat din ahlâklılığa güç, güzellik ve gerçeklik kazandırır (Immanuel Kant, 2007). Kant dinden ahlâk üretilemez derken birtakım teoerisyenler ise, ahlâki ödevlerin koşulsuz geçerliliğini öne süren Kant'ta Tanrısal emirlerin otoritesini işitmemenin mümkün olmadığını düşünmektedirler. Onlara göre Kant etiği Ortaçağ dini etiğinin modern versiyonudur. (Tüzer, 2015). Nietzche'ye göre Kant'in başarısı salt Tanrı bilimci başarısıdır ve o nesnel, zorunlu ve evrensel ahlâk yasasından bahsetse de bu teologlarla aynı dili konuşmaktır. Tüzer'e göre ise, Kant Aydınlanma'nın büyük öncüsü olsa da kazanımlarını büyük ölçüde teolojik mirasa borçludur. Yaptığı sadece dinsel etik sistemini değiştirmeden merkezi bir kavramın yerine seküler bir kavram koymaktır. Sözgelimi, Tanrı'nın yerine aklı, ilahi buyruk yerine ahlâk yasasını, Tanrı'ya itaat eden kulun yerine akla itaat eden bireyi cennetin yerine en üstün iyiyi, Tanrı'nın krallığı yerine evrensel akıl dinini/etik devleti/hakiki kiliseyi koymak gibi (Tüzer, 2015). Kant, kutsiyet atfettiğimiz birtakım şeylerin zorlamasıyla yapılan eylemin etik olamayacağını aynı zamanda gerçekleştirilemeyeceğini dile getirir. Ancak birtakım teorisyenler Kant 
böyle ifade etse de onun etiğinin teolojik unsurları taşıdığını iddia etmektedir. O halde buradan teoloji temel alınarak bir meslek etiği oluşturmak mümkündür denilebilir. Öte yandan Kant'ın kendi ifadesi dikkate alındığında ise şöyle bir değerlendirme yapılabilir. Bütün ahlâki değerler Peygamber'in sözü ve fiili olarak bilinse bile uygulama kısmında eylem, var olan duruma göre gerçekleştirilir veya gerçekleştirilmez. Bizdeki kutsiyet, zorla yapılan bir eylem değil, fakat sanki isteyenin yapacağı ya da hiç yapmayacağ 1 bir eylem olarak gerçekleşmektedir. Kişi çalıştığ 1 kurumda amiri tarafından kontrol ediliyorsa işler vaktinde yerine getirilir. Kontrol edilmiyorsa işler yerine getirilmekle birlikte aksatıldığı zamanlar da olur. Dinimizde en önemli etik değerlerden biri "Kul hakkı"dır"

Kant, saf aklın ilkelerine yükselip onlara yeterince ulaştıktan sonra bu yaygın kavramlara inmek, kuşkusuz çok övülmeye değer olduğunu düşünür. $\mathrm{Bu}$ da ahlâk öğretisini ilkin metafiziğin üzerinde kurmak sonrada ayakları üzerinde sağlam durunca onu yaygınlaştırmak kabul görmesini sağlamak demek olur (Kant, 2013, s. 25). Ahlâk metafiziği ise yalnız ödevlerin bütün teorik, kesin olarak belirlenmiş bilgisinin onsuz olunamayacak bir taşıyıcısı değil aynı zamanda kendi buyurtularının gerçekten yerine gelmesi için son derece arzu edilen bir şeydir. Oysa duygu eğilim güdüleri ile aynı zamanda da akıl kavramlarının karışımından oluşan bir etik, etik öğretisi, insanın ruhsal yapısının hiçbir ilke altında toplanamayan sık sık kötüye ancak rastlantısal olarak iyiye götürebilen hareket nedenleri arasında gidip gelmesine neden olmaktadır (Kant, 2013, s. 27). Kant gibi meslek etiğini de ilkin metafizik içerisinde temellendirmek daha sonra da yaygınlaştırılmasını sağlamak mümkün olabilir mi? Öte yandan Kant, "Saf Aklın Sınırları Dahilinde Din", adlı eserinde, ahlâk kaçınılmaz bir şekilde bizi dine götürür demektedir. Kant'a göre, en iyi olan bir Tanrı'nın varlığı, insanı nihai gayesi olan daha güçlü bir ahlâki kanun yapıcı fikrine götürür (Kant, Saf Aklın Sınırları Dahilinde Din, 2017) ifadesi yukarıdaki eleştirileri doğrulamaktadır. Görüldüğü gibi Kant'a göre, Tanrı fikri bizi ahlâklı olmaya götürür. Kant'a göre ahlâk ilk olarak metafizikle temellendirilmelidir. Burada Kant'1n, daha önce ifade ettiğinin dışında bir ifade kullandığı görülür. Bu durumda Kur'an-1 Kerim ve Sünnet’ten bir meslek etiği oluşturmak mümkündür.

\section{2. İlahiyatçı için Mesleki Etik İlkeler}

İlahiyatçı için mesleki etik ilkeleri belirlerken Kant'ın etik temellendirmesi temel alınmıştır. Bu temellendirmede ahlâki eylemin kurucu şartlarını içeren transendental yöntemle birlikte analojik yöntemi ve diskürsif yöntemi de gözönünde bulundurarak birtakım mesleki etik ilkeler oluşturulmuştur. Her ne kadar Kant'ın etik anlayışı birtakım teoerisyenler tarafindan teolojik olduğu için eleştirilmiş olsada yine de Kant etiği deontolojik olarak pek çok etik anlayışa öncülük etmişitir. Bu çalışmada Kantvari bir etik düşüncesi oluşturma çabası içerisinde kendi kültürel geçmişimiz ve teolojik alt yapımız dikkate alınarak birtakım ilkeler oluşturulmuştur. Belki bu nedenle sübjektif bakış açısıyla bir meslek etiği oluşturulduğu düşünülebilir. Ancak bu çalışmada öne sürülen ilkeler hem bireyi hem de geneli içine alacak şekilde ifade edilmeye çalışılmıştır ve sadece bir meslek mensubunun değil, herhangi bir meslek mensubunu da içine alabilecek düzeyde sıralanmıştır.

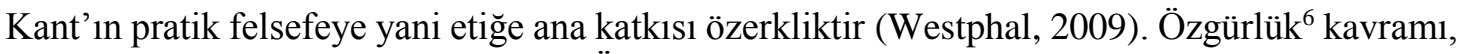
istemenin özerkliğini açıklamanın anahtarıdır. Özerk olmak, özgürlüğe ve hakikat amacına bel bağlamış olduğumuz anlamına gelir. Özgür olmak istiyorsak hiç kimse bize ne düşünmemiz gerektiğini söylememelidir (Tüzer, 2015). Epiktetos'a göre, engellerden bağımsız, yaptığı her şeyi dilediği gibi yapan bir adam özgürdür. Engellenmiş, zorlamalara maruz kalmış ya da iradesine aykırı bir durumdaki adam ise köledir (Bakış, 2015). Kant da Epiktetos ile aynı fikri paylaşır, fakat farklı bir şekilde ifade

\footnotetext{
${ }^{5}$ Bkz.Kur'an-1 Kerim, En'am Suresi 152. ayet, Araf Suresi 85. Ayet, Hud Suresi 84-85. ayetler, İsra Suresi 35. Ayet, Rum Suresi 38. Ayet, Şuara Suresi 181., 183. Ayetler, Hac Suresi 60. Ayet, Teğabun Suresi 14. Ayet, Mutaffifin Suresi, 1-3. Ayetler. "Serbest olma, bir şeye bağlı olmama, etki almama, seçme gücü ve imkanı olması." Bolay, a.g.e., s.334; "(ing.freedoom, liberty, Fr. Liberte, Al.freiheit) Kişinin kendi kendisini belirlemesi, denetlemesi, yönlendirmesi durumu. Ahlâki öznenin kendi tercihlerine akla dayalı kararlarınai iradesinin buyruklarına göre eyleyebilmesi durumu. " Cevizci, a.g.e., s.729
} 
eder. Ona göre, özne gönlünce bu yasaya uymak ister, fakat başka otoriteler tarafından bu yasaya uymaya zorlanır. Dolayısıyla Kant için bu tavır ödev olamazdı. Bu buyruk da ahlâksal emir olarak kabul edilemezdi. Bundan dolayı Kant, heteronomi/yaderliliğin karşısına istemenin özerkliği/otonomi ilkesini koyar (Kant, 2013, s. 64); (Pieper, 2012, s. 185). Çünkü Kant'a göre akı1lı varlıkların duyumlarla algılanabilir doğası, onların deneysel olarak belirlenmiş yasalar içindeki varoluşudur. Bu nedenle de biyolojik, duyusal varlığı olan akıl dışarıdan belirleyen heterenomi özelliği taşır. İnsan kendini "doğanın" parçası olan yanıyla yoklayıp eleştirel bir süzgeçten geçirerek iradesinin içinde bir ayrım yapar: Kendini dıştan belirtmek ile kendini belirlemek arasındaki ayrım budur. Kant iradenin kendi belirlemesini anlatmak için otonomi; yani özerklik kavramını kullanır (Kant, 2013, s. 64). Meslek etiğini oluşturanlar özerk olmalıdır denilebilir mi? Mesleki ilkeler oluştururken her ilahiyatçı kendini otonom olarak kabul eder. Yani bu ilkeler bütün ilahiyatçıları kapsayacak güçte olmalıdır. Birinci ilke, "Kendini otonom olarak kabul ettiğin yasaya göre davran!"dır.

Kant'a göre, akıl insanı bir yasaya saygı duymaya zorlar. Pratik yasaya saf saygıdan gelen eylemin zorunluluğu, ödevi oluşturan şeydir. Çünkü o, değeri herşeyin üstünde olan kendi başına iyi istemenin koşuludur. Kant'a göre, sıradan bir insanda bile etik bilgisi vardır (Kant, 2013, s. 19); (Pieper, 2012, s. 144). Yani bu ilkeyi oluşturabilmek güç her insanda vardır. Ancak etik yasasını yerine getirmenin bir ödev olduğuyla hareket etmek gerekir. Her ilahiyatçının kendine ait bir yasası olmalı bu yasa genele de indirgenebilmelidir. Söz gelimi, "Insanların mallarını ve haklarını eksiltmeyin. Yeryüzünde bozgunculuk yaparak karışıklık çıkarmayın! "(Kur'anı Kerim) ayeti kerimeyi hem bireysel ilke hem de genel ilke olarak düşünmek mümkündür. Bu ifadeyi her ilahiyatçı bu ilkeyi hem bireye hem de genele uygulanabildiği için kabul edebilir. İkinci ilke, "Yaptığın eylemde hakkı gözet ve adaletle hükmet!" dir.

Kant etiğinde insanın bir eylemi isteyerek gerçekleştirmesi üzerinde durur. Bu durumda karşımıza irade ${ }^{7}$ kavramı çıkar. Dünyada ve dünya dışında bile iyi bir istemeden başka kayıtsız şartsız iyi sayılabilecek hiçbir şey düşünülemez. İyiyi isteme mutlu olmaya layık olmanın bile vazgeçilmez bir koşulunu oluşturur (Kant, 2013, s. 8); (Pieper, 2012, s. 140). Çünkü basiret sağlam bir zekayı ahlâklılık da iyi niyeti gerektirir (Immanuel Kant, 2007, s. 30). İrade Kant da iyi niyet-iyi istek yani kanuna uygun hareket etmeyi düzenleyen etiğin isteklerine uygunluktur (Bolay, 2004). Kant, geleneksel etik anlayışının aksine, etik olmanın özünün etik eylemde değil de onun niyetinde bulur. Etik olanı temellendiren iyi niyettir. O halde iyi niyete dayalı ve ödev duygusundan doğan eylemler, sonucu ne olursa olsun etik bir eylemdir. Bu niyet menfaate bir ferdin ve zümrenin menfaatine dayandiysa kötülüktür (Erdem, 2012, s. 45). İyi isteme saf aklın belirlediği isteme, insanın değerini koruyan istemedir. Hatta bu dünyanın dışında iyi istemeden başka kayıtsız şartsız iyi denebilecek hiçbir şey yoktur (Kuçuradi, 2013, s. 86). Kant, etik eylemin gerçekleşmesinin odak noktasına "iyi niyet" kavramını koymaktadır. İyi niyet, Kant'ın etik teorisi insanın özgür olduğu ve ahlâki kanaatlerine dış güçlerin etkisiyle değil iç muhakeme ile ulaştığı inancından doğar. Etik, iyiliğin tek belirleyicisi olarak iyi niyete yaptığı vurgudadır (Billington, 2011, s. 155-156). Sadece Kant da değil geleneğimizde de iyi niyete vurgu yapıldığı görülür. Nitekim Hz. Peygamber'in, "Ameller niyetlere göredir. Bir kimsenin, niyet ettiği ne ise eline geçecek olan da ancak odur." sözü ile "Allah sizin suretlerinize ve mallarınıza değil, kalplarinize ve niyetlerinize bakar." (Erdem, 2012, s. 72) bunun açık delilidir. Dolayısıyla bir meslek etiği için ilkeler belirlenecekse iyi niyeti gözönünde bulundurmak yerinde olacaktır. Yani bir ilahiyatçı görevini yerine getirirken iyi niyeti öncelemesi gerekir. Bir ilahiyatçının meslek etiği ilkelerinden biri de iyi niyetli olmaktır. Bu durumda üçüncü ilke, "Yaptığın eylemi iyi niyetle yap!" tır.

\footnotetext{
${ }^{7}$ İade, isteme, dileme, ; iradei cüziyye, insanın eline bırakılmış olan istek ve ihtiyar.Sami, a.g.e., s.529;"'Yeti olarak, bir takım motif ve sebeplere göre eylemi belirleme gücü. Özgürlüğü ihtiva eden istek. " Süleyman Hayri Bolay, Felsefe Doktrinleri ve Terimleri Sözlügü, Akçağ Yayınları, Ankara 2004, s.218-219
} 
İyi niyet ile birlikte doğada ${ }^{8}$ herşey yasalara göre hareket eder. Yalnızca akıl sahibi bir varlığın yasaların tasarımına göre, yani ilkelere göre eylemde bulunma yetisi ya da istemesi vardır. Yasalardan eylemleri türetmek için akıl gerekli olduğu için isteme pratik akıldan başka bir şey değildir. Nesnel bakımdan zorunlu olduğu bilinen eylemler öznel olarak raslantısaldır (Kant, 2013, s. 29). Kant insanın hem kendi doğasına uygun hem de doğa yasalarına uygun yasaların yapılması gerektiği üzerinde durur. $\mathrm{Bu}$, insanın doğuştan güzel ve iyiye meyilli olarak dünyaya gelmesidir. Dolayısıyla en güzel şekilde bir varlık olarak insan güzele meyillidir. Oluşturulacak etik ilkeler için hem doğa yasaları hem de insan doğasının dikkate alınması önemlidir. Etikle insanın bağı özünden geldiği için doğası temel alınarak oluşturulacak etik ilkeler her daim kalıcı olacak ve genelde insanın gelişimine özelde ise mesleki gelişimine katkı sağlayacaktır.

Kant'a göre, ödev kavramı iyi isteme ile birlikte bazı özel kısıtlamaları ve engellemeleri de içermektedir. Gerçekten ödeve uygun olan ama insanların onlara doğrudan doğruya hiçbir eğilim duymadıkları, ama yine de başka eğilim tarafından itildikleri için yaptıkları eylemleri de bir kenara bırakırsak ödeve uygun eylemlerin ödevden dolayı $\mathrm{m} 1$ yoksa bencil bir amaçtan dolayı $\mathrm{m} 1$ yapıldığı kolayca ayırt edilebilir. Eylemin ödeve uygun olduğu, öznenin de ayrıca buna doğrudan doğruya bir eğilim duyduğu eylemlerde bu ayırımı yapmaksa çok daha zordur. Örneğin bir bakkalın deneyimsiz müşterisini aldatmaması ödeve uygundur. Zeki bir tüccar da bunu yapmaz. Herkes için değişmez bir fiyat koyar. Dolayısıyla insanlara dürüstçe hizmet edilir. Tüccar bunu ödevden ve dürüstlük ilkesinden yapmaz. Demek ki eylem ödevden dolayı ya da doğrudan doğruya eğilimden dolayı değil sırf bencil amaçla yapılmıştır (Kant, 2013, s. 12-13). İstemenin özgürlügü̈ özerklikten başka, yani istemenin kendi kendine yasa olma özelliğinden başka ne olabilir? "İsteme, bütün eylemlerde kendisi bir yasadır" önermesi ise yanlızca "kendini genel bir yasa olarak da nesne edinebilecek maksimden başka hiçbir maksimle eylemde bulunmama" ilkesine işaret eder. Bu ise tam kesin buyruğun ve ahlâkl1lık ilkesinin formülüdür: demek ki özgür bir isteme ile ahlâk yasaları altında olan bir isteme aynı şeydir (Kant, 2013, s. 65) Platon, mağara alegorisi ile insanları köleleştiren zincirlerden kimin sorumlu olduğu sorusuna yanıt vermemiştir. Kant, zincirlerin bizzat eyleme geçmek, bizzat düşünmek yerine tembellikten ve rahatından vazgeçmeyip başkalarının kendilerini vesayet altına almasını tercih eden ve bu ergin olmayış durumundan bizzat sorumlu olan insanları gösteren bir simge olduğunu ifade ederek cevap vermiştir (Pieper, 2012, s. 179). Başka bir ifadeyle Kant etiği başkalarının buyruğuyla değil de kendi buyruğuyla özgürce hareket edebilmektir. Dolayısıyla insanların eylemleri düşünerek değil bencil amaçlar için yaptıklarını görmek mümkündür. Bu da insanların ödev idesiyle eylemleri gerçekleştirmediği sonucuna bizi götürür. Nitekim bir ilahiyatçı herkes bana iyi ilahiyatçı desin diye mesleğini icra ederse bu ödeve uygun değildir. Yani ödeve uygun davranış o ilk ilkeye vurgu yapan davranıştır. Böylesi davranış birilerinin size iyi dediği için değil, ödev olduğu için böyle davranabilmektir. O zaman bir ilahiyatçı, mesleğini gerçekleştirirken birilerine hoş görünmek için değil hakikatte öyle davranmanın iyi olduğu bilinciyle hareket etmelidir. Bu durumda dördüncü ilke, "Eylemi birileri sana iyi desin diye değil, öyle davranmak iyi olduğu için yap!" tır.

Kant, mutluluğun araç olarak kullanılmaması üzerinde özellikle durur. Çünkü ona göre, mutluluk insanın ister kendi şahsında ister başka bir insanın şahsında yanlızca bir araç değil, aynı zamanda bir amaçtır (Kant, 2013, s. 45);(Feldman, 2016). Mutluluğu tam olarak ifade etmenin imkansızlığından söz etmektedir. Mutluluğu belirli bir kavram ile ifade etmek aynı şekilde kolay olsaydı, zekâ buyrukları beceri buyruklarıyla tastamam uyuşurdu. Ama ne yazık ki mutluluk kavramı öylesine belirsiz bir kavramdır ki her insan ona ulaşmayı dilese de hiçbir zaman kesinlik ve tutarlılıkla aslında ne dilediğini söyleyemez. Bunun nedeni mutluluk kavramını oluşturan öğelerin hepsinin deneysel olmasıdır. Bununla birlikte mutluluk idesi için, şimdide ve gelecekteki her durumda da esenliğin en büyüğü gereklidir. Mutlu kılan şeyi yapmayı dar anlamda buyuran bir buyruk olamaz.

${ }^{8}$ Doğa, (Yun.Physis,İng,Nature. Fr. Nature, Al.natur) Bir organizmanındoğuştan getirdiği ya da miras bıraktığı varsayılan özellik ya da karakteristiklerin bütünü,maddi evreni gösterir. Cevizci a.g.e., s.269. 
Çünkü mutluluk aklın bir ideali değildir. Sırf deneysel nedenlere dayanan hayal gücünün bir idealidir (Kant, 2013, s. 34-35). Kant'a göre, erdem ${ }^{9}$, ahlâkilik ve akılc1lığa ulaşmak mutluluğa ulaşmaktan daha önemli görülmekte ve ödev ilkesini mutluluk ilkesinin önüne koymaktadır (Pieper, 2012, s. 131). Kant'a göre eğilimden dolayı değil ödevden dolayı kendi mutluluğunu koruma yasası, ilk defa burada davranışın hakiki ahlâksal değerini ortaya çıkarır (Kant, 2013, s. 14). Kant'a göre, insanın kendi mutluluğunu koruması sırf eğilimden değil yasadan dolayı ise ödevdir ve ahlâki bir değer taşır. Kant mutlu olmayı deneysel olarak nitelendirdiği için herkese göre mutluluk idealinin farklılığı üzerinde durur. Bu durumda Kant belki de haklıdır. Ancak bir mesleki yaşantıda çalışanların hem kendilerinin mutlu olması hem de meslek mensuplarının hem de çalışma arkadaşlarını mutlu etmesi da beklenilen bir şeydir. Çünkü mutluluk meslekte motivasyonu artıran bir şeydir. Bu durumda meslek etiği ilkeleri içerisinde mutluluk bir araç değil de amaç olarak ele alınmalıdır. O halde denilebilir ki mesleki etik ilkelerinden beşincisi kurum içinde çalışanların mutlu olmasıdır. Her şeyden önce meslek mensuplarının işlerini aşkla yapmaları mutluluğun anahtarı olacaktır. Beşinci ilke, "İşini aşkla yap ve mutlu ol!" dur.

Kant, insanın yaşamını sürdürmesinin ödev olduğunu düşünür ve her insanın yaşamı sürdürmeye doğrudan doğruya eğilimi olduğunu iddia eder. Fakat ona göre, insanların yaşamlarına gösterdikleri ehemmiyet neticesinde oluşan öznel pratik yasanın hiçbir ahlâksal değeri yoktur. Buna karşılık eğer talihin kötü cilveleri ve umutsuz acı, yaşamdan tat almayı büsbütün yok ettirdiyse, ruhu güçlü olan mutsuz kişi, cesareti kırılmış ya da yıkılmış olmaktan çok alınyazısına küserek ölmeyi dilerse ama yaşamını onu sevmeden eğilimden ya da korkudan değil, ödevden dolayı yine sürdürüyorsa; işte o zaman maksimin ahlâksal içeriği vardır (Kant, 2013, s. 13). İnsanın kendine karşı ödevleri birinci koşuldur ve ahlâklılık ilkesidir. Çünkü kişinin değeri ahlâksal değerini oluşturur. Soktates hiçbir değeri olmayan çok kötü bir durumdaydı, ama bu durumda bile kişiliğinin değeri çok yüksekti. İnsanın kendine karş1 ödevlerinin ihlal etmesinin üst aşaması intihardır. Bu davranışın iğrençliği nereden ileri gelmektedir? Tanrı intiharı yasakladığı için iğrenç değildir, tersine intihar iğrenç olduğu için Tanrı onu yasaklamıştır (Immanuel Kant, 2007) Kant'a bakıldığında insanın bir Tanrı'nın varolduğu inancına götüren ahlâktır. Bir insan görevini yerine getirirken bir Yaratıcı'ya boyun eğme ihtiyacı vardır. Ödevinden saparsa hesap vereceği bir yargıcın varlığı akıl sahibi insanı ahlâki bir Varlık'a muhtaç kılar (Aydın, 1981). Ahlâksal içeriği olduğu için bu ödevin varlığı ehemmiyet arz etmektedir. İnsanın hem beden hem de akıl sağlığını koruması en önemli mesleki ilkelerden biri olarak kabul edilir. Böylece ödev içeriğinde kendine yer bulur. İlkin bir meslek mensupu kendini sakatlayacak, bozacak ya da öldürecek şekilde davranamaz. İnsanın kendini koruması asıl etiğe girer (Kant, 2013, s. 47). Kendine karşı ödevleri yerine getirmenin öznel koşulu kendine hakim olmaya çalışmaktır. Kant'ın bununla ilgili olarak oluşturduğu ilke, "Şerefli yaşa, hiçbir zaman incitme, kendini ve başkalarını olduğu gibi kabul et!" tir (Immanuel Kant, 2007). Mesleki etik ilkelerden altınıcısı kişinin kendini korumasıdır. Nitekim Kur'an'da hem insanın kendine zarar vermesini hem de intiharı men eden ifadeler varır. Şöyle ki, “...Kendi canınıza kıymayınız/intihar etmeyiniz" ve “...Kendi ellerinizle kendinizi tehlikeye

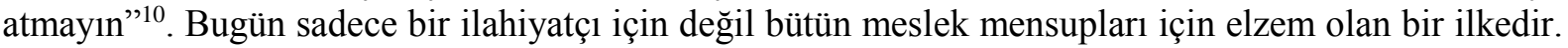
Özellikle bugün herhangi bir meslek mensubunun intihar eğilimleri ${ }^{11}$ bu ilkenin diğer ilkelerden daha da önem arzettiğini göstermektedir. Bu durumda altıncı ilke, "Kendini ve başkalarını olduğu gibi kabul et; kendini ve başkalarını incitme; kendinin ve başkalarının canına kıyma!"dır.

Öte yandan Kant, insanın ben sevgisini abartmaması gerektiği üzerinde durmaktadır. Günümüzdeki etik ihlallerinin nedenlerinden bir tanesi de insandaki ben sevgisinin olduğu görülmektedir. Kant'a göre, insan sevgisinden dolayı eylemlerimizin çoğunun ödeve uygun oldukları kabul edilebilir. Ama onlara daha yakından bakıldığında her yerde ortaya firlayan sevginin temelinde

\footnotetext{
9“Arete, üstünlük, erdem, fazilet. Bir yunanlı için kemal ve ahengde hoş olan.” Francis E. Peters, Antik Yunan Felsefesi Terimleri Sözlüğü, Çev ve Haz: Hakkı Hünler, Paradigma Yayınları, İstanbul 2004, s.46.

${ }^{10}$ Kur'anı Kerim, Nisa 29, Bakara 195

${ }^{11}$ Bkz. Serdar Süleyman Can, Buket Göngör, Rüstem Aşkın, Kriz Dergisi, Hekim İntiharları, s.33-39.
} 
ödev değil ben vardır. İşte burada ödev idelerini büsbütün yitirmemek ve ödev yasasına beslenilen saygıyı ruhunda korumak açık inançtan başka hiçbir şey sağlayamaz (Kant, 2013, s. 23). Kant'a göre erdemin gerçekliğine inanmak başka anlamda inançtır. Erdemin gerçekliğine inanmamak da ahlâksal inançsızlıktır (Immanuel Kant, 2007). Meslek etiğinde bireyin kendini korumasıyla birlikte insan olmaktaki ideal kaybedilmediği takdirde gerçek anlamda ilkelerine duyarlı ilahiyatçılar yetişebilir. $\mathrm{Bu}$ durumda yedinci ilke ben sevgisinden kaçınmaktır. Aşırı ben sevgisi bir meslek mensubunu mesleki ihlallere sürükleyebilir. Yedinci ilke, "Ben sevgin, başkalarının hakkını gözardı etmene izin vermesin!" dir.

Kant, ahlâkın yaşanılması gereken bir şey olduğunu ve dolayısıyla ahlâklılığı örneklerle göstermeyi istemenin ahlâkl1lığa yapılabilecek en büyük kötülük olduğunu dile getirir. Hiçbir zaman ahlâkl1lık kavramı yetke ile sağlanamaz. Kant şöyle der: "Bana neden iyi diyorsunuz görmediğiniz biricik Tanrıdan başka hiçkimse iyinin modeli değildir (Kant, 2013, s. 24-25); (Maclntyre, 2001). Bizde de Hz. Peygamberin ve sahabenin örnek ahlâkından her daim bahsedilir ancak var olan bu örnekler kutsallaştırıldığı için hiç yapılamayacak bir eylem gibi algılanır. Genelde İslam dininin bütün mensupları, özelde ise İlahiyatçılar bütün ahlâki kaideleri örnekleri ile birlikte bilirler fakat bazılarını eyleme dönüştürürken bazılarını eyleme dönüştüremezler. O zaman bir ilahiyatçı olarak öze dönerek ahlâkın yaşanılması gereken bir olgu olduğunu görmekgerekir. İnsanın bildiğini eyleme dönüştürdüğünde varoluşunu gerçekleştirebileceği düşünülünce meselenin önemi ortaya çıkmaktadır. Çünkü ahlâki ilkeler, uygulanmalı ki toplumsal düzen ve adaletten söz edilebilsin. Dolayısıyla mesleki ilkerlerden en önemlisi yani sekizincisi, etik ilkelere uymak, yani ilkeleri yaşamaktır. Bu da ancak içselleştirmekle olabilecek bir şeydir. Sekizinci, "Bildiğin değerlere göre eylemde bulun! dir.

Bütün meslekler, el sanatları ve sanatlar arasında bir işbölümü vardır. Çünkü o zaman bir kişi her şeyi yapmaz; herbiri, bir işi en yetkin ve en kolay şekilde yapabilmek için yapılışı bakımından diğerlerinden gözle görülür bir biçimde farklı olan bir işi yapmakla yetinir. İşlerin bu şekilde ayrılıp bölünmediği, herkesin her telden çalar olduğu yerde, meslekler hala en büyük barbarlık durumundadır (Kant, 2013, s. 3). İnsanın en yetkin işi kendi mesleğidir. Mesleki etik açısından en önemli husus herkesin uzmanlık alanı ne ise o alanda hizmet vermesi ve kendini o alanda geliştirmesidir. Herkesin her konuda uzman olmaya çalıştığı bir ortamda bir mesleğin varlığından söz etmek imkansızdır. Bu da meslek etiği ile ilgili olarak dikkat edilmesi gereken hususlardan biridir. Bu durumda dokuzuncu ilke ilahiyatçıların kendi alanında uzman olmasıdır. Bu ilke ilahiyatçı için de en temel ilkelerden biri olmalıdır. Dolayısıyla dini bildiğini iddia eden herkesin sözüne itibar etmemek gerekir. O öznenin ne alanda uzman olduğu sorgulanmalıdır. Dokuzuncu ilke, "Uzman olduğun alanda söz sahibi ol, uzman olmayanların senin alanında söz söylemelerine izin verme!" dir.

Kant'a göre, insanlar hem kendilerine hem de başkalarına hiçbir zaman sırf araç olarak davranmamaları gerektiğini düşünmektedir. Ancak insanların hepsi aynı amaç için birleştirkleri bir yasaya göre hareket ederler. Bundan insanların ortak yasalar aracılığıyla oluşturdukları bir krallık ortaya çıkar ki ortak amaçla bir araya gelen insanların oluşturdukları bu krallığa amaçlar krallığı adı verilir. Ama insan, bu amaçlar krallığında hem genel yasa koyucu olarak bulunur hem de bu yasalara kendisi bağlı olursa bu krallığın bir üyesi olur. Ödev, amaçlar krallığında kral olana değil, bu krallığın bütün üyelerine aynı derecede yakışır (Kant, 2013, s. 51-52). Yasa bütün gücünü korur, çünkü kesin bir şekilde buyuran bir yasadır. Bu biricik, sonsuz, sınırsız yasa koyucu, hem insanların değerini tek başına oluşturur hem de yargılanacak kim olursa olsun onun yargılanmasında dayanılacak yasadır. Bu en yüksek varlık olsa da yasa önünde herkes eşittir. Dolayısıyla amaçlar krallığı ancak bir doğa krallığ1 analojisiyle olanaklıdır (Kant, 2013, s. 56-57). Amaçlar krallığında herşey değerlidir. Özerlik insanın her akıl sahibi varlığın değerinin temelidir (Kant, 2013, s. 52). Tüzer'e göre Kant, Tanrı'nın yeryüzündeki krallığını yıkmış insanı özgür ve özerk bir varlık kılmış ahlâk yasasının yegâne kaynağı olarak aklı göstermiştir ve aklın mutlak krallığını ilan etmiştir. Bu da onu teologlar sınıfından koparıp modern aydın kılan şeydir (Tüzer, 2015). Tüzer bu konuda doğru tesbit de bulunmuş olabilir. Belki de 
Kant insanın Tanrı gibi mükemmel olamayacağını ancak gerçek anlamda insan olmanın amacını bilirse, yani akıl sahibi olmak sorumluluk sahibi olmak demektir. Sorumluluğunu bilen bir amaçlar krallığı da oluşturabilir. İlahiyatçı olmak aydın olmaktır. Aydın olmak da birtakım amaçları için varolan ve bu amaçları doğrultusunda topluma yön veren bireydir. Dolayısıyla bir ilahiyatçının meslek etiği ilkelerinden onuncusu bir amaçlar krallığı oluşturmaktır $\mathrm{Bu}$ amaçlar krallığı iyi ilahiyatçıların yetişmesini sağlamakla birlikte ilahiyatçıların belli konularda ortak etik ilkeler oluşturmalarına kaynaklık edebilir. Biz ilahiyatçıların genel mesleki amaçları nelerdir? Bu amaçlar iyi belirlenirse topluma ortak amaçlarla yön veren ilahiyatçıların yetiştirilmesi sağlanabilir. Onuncu ilke, "İyi bir ilahiyatçı olabilmen için bütün ilahiyatçıları biraraya getirecek ortak amaçların olsun!"dur.

\section{Sonuç olarak}

Kant etiğini transendental, diskürsif ve analojik olarak temellendirdiği görülür. Kant transendental yöntem ile etiği oluşturan kurucu ilkeyi bulmayı amaçlarken özellikle özgür irade üzerinde durmaktadır. Diskürsif yöntem ile fiilen geçerli olan normları meşrulaştırmaya çalışır toplum için başka hangi normları oluşturma çabası içerisine gimektedir. Analojik yöntemle de toplumdaki genel tarafından benimsenmiş normları ve değerleri, belli bir durumla ilişkilendirmiştir.

Kant'a göre bir meslek etiği oluşturabilmenin yolu felsefeyi temel almaktır. Kant felsefeyi temel almak derken metafiziği temel alarak etiğin oluşturulması gerektiğini düşünmüştür. Kant metafiziği temel aldığ 1 için onun etiğini teolojik etik olarak değerlendirenler vardır. Belki bu eleştiriler Kant'ın birbirileriyle uzlaşmaz ifadelerinden kaynaklanmaktadır. Çünkü Kant, bir yerde din bizi etiği götürmez demektedir; başka bir yerde de Tanrı fikri bizi etiğe götürür demektedir. Bu eleştirileri bir kenara bırakırsak eğer Kant söylendiği gibi teolojik temelli bir etik oluşturmuşsa ve bu etik bugün deontolojik etiğin temelini oluşturuyorsa Kant etiği temel alınarak bir ilahiyatçı etiği oluşturulabilir sonucuna varılabilir. O halde mesleki etik ilkeleri oluşturuken dini kaynak olarak kullanmak mümkündür. Kant, kutsiyet atfettiğimiz varlıklardan etik oluşturulamayacağını ifade etse bile yine de Tanrı sevgisiyle ifade edilen etik yasanın etiğe güç vereceğinden bahsetmektedir. Dolayısıyla bir ilahiyatçı için etik yasalar, Kur'an'a ve Sünnet'e dayalı olarak oluşturulabilir. Kant'a göre etik insanı temel almalıdır. Çünkü evrende yegâne eylemlerinin sorumluluğunu bilen ve düşünen varlık insandır. Etik insanı temel alırsa meslek etiği de insanı temel alacaktır. Kant'a göre, insan etik ilkeleri oluştururken hem aklını hem deneyimini kullanır. Kant etik temellendirmede insanın doğası ve doğa yasasını dikkate almak gerektiği üzerinde durur. Kant'a göre, etik yasalar, zorunluluk taşısa bile eylem gerçekleştirilirken hem saygıyı hem de sevgiyi birarada bulundurup gerçekleştirilir. Kant etiği, otonom varlık olarak insanı, en yüce iyiyi, iyi niyeti ve iradeyi temel alır. İlahiyatçı için mesleki etiğini bu dört esasa göre temellendirilmeye çalış1lmıştır. Bunun sonucunda şu on ilke belirlenmiş̧ir: 1. Kendini otonom olarak kabul ettiğin yasaya göre davran! 2. Yaptığın eylemde hakkı gözet ve adaletle hükmet! 3. Yaptığın eylemi iyi niyetle yap! 4. Eylemi birileri sana iyi desin diye değil, öyle davranmak iyi olduğu için yap! 5. İşini aşkla yap ve mutlu ol! 6. Kendini ve başkalarını olduğu gibi kabul et; kendini ve başkalarını incitme; kendinin ve başkalarının canına kıyma! 7. Ben sevgin, başkalarının hakkını gözardı etmene izin vermesin! 8. Bildiğin değerlere göre eylemde bulun! 9. Uzman olduğun alanda söz sahibi ol, uzman olmayanların senin alanında söz söylemelerine izin verme! 10. "İyi bir ilahiyatçı olabilmen için bütün ilahiyatçıları biraraya getirecek ortak amaçların olsun!

Yukarıda ifade edilen on ilkeyi bir ilahiyatçı için mesleki etik ilkeler olarak olarak belirlenmiştir. Bu belirleme ile deontolojik bir meslek etiği oluşturulmuştur. Bu norm koyucu tarafimız nedeniyle tam olarak diskürsif yöntemi kullanmadığımızı idda edenler olacaktır. Normları betimlemek ve meşrulaştımaktan öte bir otorite olarak kuralların konulduğu iddia edilebilir. Ancak çabamız bir ilahiyatçının oluşturduğu bireysel yasayı genel yasaya dönüştürmek çabasıdır. Eleştirilecek başka bir konu da teolojiden etik temellendirme yapmaktır. Burada Kant kaynak gösterilmiştir. 


\section{KAYNAKÇA}

Akalın, Ş. H. (2011). Türkçe Sözlük. Ankara: Türk Dil Kurumu Yayınları.

Aydın, M. S. (1981). Kant'ta Ve Çağdaş İngiliz Felsefesinde Tanrl-Ahlâk İlişkisi. Ankara, Umran Yayınları.

Bakış, R. (2015). Epiktetos'un Stoik Ontolojide Irade Ve Özgürlüğe Yer Açma Çabası, Turkish Studies International Periodical For The Languages, Literature And History Of Turkish Or Turkic Volume 10/10 Summer 2015, P. 167-180 Dor Number: Http://Dx.Doi.Org/10.7827/Turkishstudies.8351 Issn: 1308-2140, Ankara-Turkey

Bilington, R. (2011). Felsefeyi Yaşamak Ahlâk Düşüncesine Giriş. (A. Yılmaz, Çev.) İstanbul: Ayrıntı Yayınları.

Bolay, S. H. (2004). Felsefe Doktirinleri Ve Terimleri Sözlüğü. Ankara: Akçağ Yayınları.

Bowie, N. E. (2009). A Kantian Approach To Business Ethics. R. E. Frederick (Dü.) İçinde, Busıness Ethics And Normative Theorles (S. 1-16).

Çakıroğlu, N. Ö.-D. (2012). Meslek Etiği. Ankara: Nobel Yayınevi.

Özlem D. (2004). Etik Ahlâk Felsefesi. İstanbul: İnkılap Yayınları.

Erdem, H. (2012). Ahlâk Felsefesi. Konya: Hü-Er Yayıncılık.

Feldman, F. (2016). Etik Nedir? İstanbul: Boğaziçi Üniversitesi.

Frenkena, W. (2007). Etik. Ankara: İmge Kitapevi.

Kant I. (2007). Ethica Etik Üzerine Düşünceler. (O. Özügül, Çev.) İstanbul: Pencere Yayınları.

(1999). Pratik Aklın Eleştirisi. Ankara: Türkiye Felsefe Kurumu.

(2013). Ahlâk Metafiziğinin Temellendirmesi. Ankara: Türkiye Felsefe Kurumu Yayınları.

(2017). Saf Aklın Sınırları Dahilinde Din. (S. B. Çağlan, Çev.) İstanbul.

Kuçuradi İ. (2013). Insan Ve Değerleri. Ankara: Türkiye Felsefe Kurumu Yayınları.

Kur'an-I Kerim. (Tarih Yok).

Maclntyr, A. (2001). Erdem Peşinde. (M. Özcan, Çev.) İstanbul: Ayrıntı Yayınları.

Pieper, A. (2012). Etiğe Giriş. (V. A. Sezer, Çev.) İstanbul: Ayrıntı Yayınları.

Silber, J. (2012). Kant's Ethics. Germany.

Timmermann, J. (2013). Kantian Dilemmas? Moral Conflict in Kant's. AGPh , 95(1), 36-64. doi:DOI 10.1515/agph-2013-0002

Tüzer, A. (2015). Tanrıyı Oynamak: Kant Etiğinin Kritiği. Beytülhikme, 5(2), 140-167.

Westphal, K. R. (2009). Kant, Hegel, and Determining Our Duties. G. W. F. Hegel; series: T. Campbell, ed., International Library of Essays in the History of Social and Political Thought, 337-336.

(2019). Modern Moral Epistemology. The Routledge Handbook to Moral Epistemology, 254-273.

Wood, A. W. (2009). Kant. (A. Kovanlıkaya, Çev.) Ankara: Dost Kitabevi Yayınları. 